\title{
PENGARUH DETERMINAN STRUKTUR MODAL TERHADAP NILAI PERUSAHAAN \\ (Studi Kasus Pada Perusahaan Properti Di Bursa Efek Indonesia)
}

\author{
Murtianingsih \\ Program Pascasarjana Magister Manajemen UMM \\ E-mail:Webmaster@unix.umm.ac.id
}

\begin{abstract}
The research was to know the effect of profitability, firm size, liquidity, structure asset, business risk, and cost of capital to capital structure at property simultaneously listed on Indonesia Stock Exchange and to know the variable which have partial effect to the capital structure. The research was taken place at Indonesia Stock Exchange Economics Faculty of Muhammadiyah University Malang. Respondent are 21 property companies listed in Indonesia Stock Exchange. Purposive sampling was used to determine companies during five-years. Secondary data was taken between the year of 2006 up to 2010. Multiple regression analysis used to know the effect of profitability, firm size, liquidity, structure asset, business risk, and cost of capital to capital structure with $5 \%$ of significance. The result of simultaneously regression (F test) exemplify that the variable profitability, firm size, structure asset, growth opportunity, liquidity, the cost of capital, business risk had significant effects to the capital structure of 21 property companies listed in Indonesia Stock Exchange. While the test of partial regression (t test), for the variable of profitability, growth opportunity, liquidity, cost of capital had effects to capital structure of property companies listed in Indonesia Stock EXchange, except the firm size, business risk, structure asset have no significant effects to the capital structure of the property companies.
\end{abstract}

Keyword: Debt to equity ratio, company size, profitability, growth, business risk and asset structure, cost of capital, liquidity

\section{PENDAHULUAN}

Perkembangan produk properti dewasa ini terlihat semakin meningkat tiap tahunnya baik itu perkantoran, apartemen maupun produk hunian. Berdasarkan data statistik tahun 2010 dari Badan Pusat Statistik kebutuhan rumah di Indonesia masih mengalami backlog (angka kekurangan kebutuhan) sekitar 13 juta unit rumah baru (http:// property.kompas.com.2011/06) Kondisi tersebut menjadi peluang bagi perusahaan properti untuk bisa menyediakan pasokan produk properti. Salah satu tantangan yang akan dihadapi seiring dengan meningkatnya kebutuhan produk properti adalah masalah pendanaan. Perbedaan dalam sumber pendanaan sangat berpengaruh pada kelangsungan hidup perusahaan.

Pemenuhan kebutuhan dana perusahaan dapat dipenuhi dari sumber internal maupun eksternal. Sumber dana internal adalah sumber dana yang dibentuk dan dihasilkan dari dalam perusahaan itu sendiri yang berupa laba yang tidak dibagikan atau laba ditahan (retained earning) Sumber dana eksternal adalah sumber dana yang diperoleh dari luar perusahaan dalam bentuk utang dan modal dari pemilik perusahaan. Sumber dana eksternal dapat diperoleh melalui pasar modal sebagai lembaga yang berperanan penting di dalam 
mengatasi kebutuhan dana. Sumber dana yang digunakan perusahaan pada hakikatnya merupakan komposisi dana atau struktur modal perusahaan. Groth dan Anderson (1997) menyatakan bahwa komposisi yang efisien dapat mengurangi biaya modal, dengan menurunnya biaya modal dapat meningkatkan return bersih dan nilai perusahaan.

Struktur modal merupakan kombinasi utang dan ekuitas dalam struktur keuangan jangka panjang perusahaan (Bernstein \& Wild, 1998 dalam Sugiharto, 2009) Struktur modal yang optimal pada perusahaan properti merupakan konsekuensi tercapainya keseimbangan antara pengembalian dan risiko keuangan yang harus ditanggung perusahaan. Struktur modal dapat diukur dari Rasio perbandingan antara total utang terhadap Ekuitas yang diukur dengan menggunakan DER (Debt to Equity Ratio) (Sheikh dan Zongjun, 2011) DER dapat menunjukkan tingkat risiko suatu perusahaan, semakin tinggi ratio DER maka semakin tinggi risiko perusahaan karena pendanaan dari unsur utang lebih tinggi dibanding modal sendiri (equity)

Teori struktur modal modern pertama kali dikenalkan oleh Modligiani dan Miller (1958), pada penelitiannya menyusun proposisi yang dikenal sebagai proposisi I dan II. Kedua proposisi intinya menegaskan bahwa bagaimanapun struktur modal perusahaan tidak berpengaruh pada nilai perusahaan. Modligiani dan Miller kemudian mengembangkan penelitian tahun 1963 menunjukkan dampak pada struktur modal perusahaan. Akan tetapi teori Modligiani dan Miller (1963) tidak mempertimbangkan faktor biaya kebangkrutan (financial distress) dan masalah agensi yang merupakan dasar dari teori trade off. Lain halnya dengan teori pecking-order, dalam teori peckingorderperusahaan menentukan struktur modal berdasarkan hierarkis preferensi tertentu. Hierarkis preferensi yang berkaitan dengan sumber pendanaan yang dipilih perusahaan.

Pengujian hipotesis pecking order telah dilakukan oleh Djakman dan Holomoan (2001) dengan menggunakan variabel defisit pendanaan internal. Hasil penelitian tersebut menyatakan defisit pendanaan internal berpengaruh positif terhadap struktur modal. Determinan struktur modal merupakan faktor-faktor yang menentukan tinggi atau rendahnya DER sebuah perusahaan. Sheikh dan Zongjun (2011) dalam penelitiannya An Empirical study of firm in manufacturing industry of Pakistan mendapati faktor-faktor penentu struktur modal meliputi: (1) Profitability, (2) Size, (3) Non-Debt tax shield, (4) Asset structure, (5) Growth opportunities, (6) Earning Volatility, (7) liquidity.

Profitabilitas perusahaan properti tentunya berpengaruh terhadap keputusan pendanaan ( $f i^{-}$ nancing decision) Seperti dalam teori Trade-off dan Pecking Orderyang mempostulatkan adanya hubungan antara profitabilitas dengan leverage. Morri dan Cristanziani (2009) mendapati hubungan negatif antara profitabilitas dengan $\mathrm{DER}$, sementara Ozkan (2001) mendapati hubungan positif antara profitabilitas dengan DER.

Ukuran perusahaan atau (firm size) diukur dengan log dari total aset Yartey (2011) Semakin besar ukuran perusahaan properti menunjukkan adanya peluang untuk menggunakan utang lebih banyak karena perusahaan besar memiliki gagal bayar atau risiko defaultyang kecil. Akan tetapi Sayilgan, Karabacak, dan Kucukkocaoglu (2006), Michael, Sumner, dan Packer (2006) mendapatkan bukti adanya hubungan positif antara ukuran perusahaan dengan DER. Sementara di Indonesia oleh Seftiani dan Handayani (2011) mendapatkan hubungan positif antara ukuran perusahaan dengan DER tetapi tidak signifikan.

Keuntungan penghematan pajak dengan menggunakan pendanaan dari utang dapat dikurangi ketika perusahaan melaporkan pendapatannya secara konsisten negatif. Penghematan pajak bukan dari utang (Non-debt tax shield) dapat mensubstitusikan penghematan pajak (tax shield) Beberapa studi empiris yang mendapati hubungan negatif antara leverage dengan non-debt tax shicld (Viviani, 2008; Bauer, 2004; Sayilgan et.al, 2004)

Tangibility (struktur asset) dalam penelitian yang dilakukan Myers dan Majulf (1984) menemukan bahwa adanya hubungan positif antara struktur aset dan leverage karena aset perusahaan dapat dijadikan sebagai agunan untuk memperoleh utang, sehingga kreditor memiliki tingkat keamanan 
apabila perusahaan mengalami gagal bayar. Sementara Yartey (2011) mendapati hubungan negatif antara struktur aset dengan DER.

Peluang pertumbuhan perusahaan bisa dicapai dari intangible asset (aset tidak berwujud) Di mana aset tersebut tidak dapat dijadikan sebagai collateral utang. Dalam Agency theory juga menyatakan adanya hubungan negatif antara pertumbuhan perusahaan dengan leverage. Beberapa temuan dalam penelitian yang menyatakan hubungan negatif antara leverage dengan pertumbuhan perusahaan (Deesomsak et. al, 2004; Zou Xiao, 2006; Eriotis, 2007)

Earning volatilityyang tinggi mengindikasikan kemungkinan besar perusahaan tidak mampu memenuhi kewajibannya pada saat jatuh tempo. Utang perusahaan dapat menurun seiring dengan pergerakan volatilitas laba yang meningkat. Kondisi tersebut menggambarkan adanya hubungan negatif antara leverage dengan carning voaltility. Beberapa studi empiris yang mendapati hubungan negatif antara earning volatilitydengan leverage (Fama dan French, 2002; Booth, et.al., Jong, et.al.)

Sesuai dengan teori Trade-offmenyarankan bahwa apabila ratio likuiditas perusahaan tinggi maka perusahaan mampu memperoleh utang lebih banyak. Sehingga teori ini memprediksikan adanya hubungan positif antara likuiditas dan leverage. Tetapi dalam teori Pecking-ordermemprediksikan hubungan negatif antara leverage dan likuiditas karena perusahaan yang memiliki tingkat likuiditas yang tinggi lebih menyukai sumber pendanaan internal. Beberapa studi empiris yang konsisten dengan teori pecking-order (Deesomsak et.al, 2004; Mazur, 2007; Viviani, 2008)

Beberapa hasil penelitian tentang determinan struktur modal memberikan hasil yang berbedabeda. Hasil penelitian yang bervariasi dapat disebabkan oleh metode penelitian, obyek penelitian dan indikator variabel serta kondisi ekonomi dan politik yang berbeda. Hal tersebut yang diangkat menjadi research gapdalam penelitian ini dengan variabel: profitabilitas, ukuran perusahaan, struktur aset, likuiditas, peluang pertumbuhan, risiko bisnis, dan biaya modal. Berdasarkan alasan tersebut peneliti ingin meneliti pengaruh determinan struktur modal terhadap nilai perusahaan pada perusahaan properti di Bursa Efek Indonesia.

\section{TINJAUANPUSTAKA}

Teori struktur modal yang tidak relevan oleh Modigliani dan Miller sebagai tonggak seperti beberapa teori yang relevan dikembangkan dengan menambahkan kondisi baru antara lain adanya informasi asimetris, biaya keagenan, financial distress, dan lainnya. Penelitian yang dilakukan Sayilgan, et.al (2006) tentang determinan struktur modal pada perusahaan di Turki, dengan menggunakan variabel ukuran perusahaan, pertumbuhan, profitabilitas, non-debt tax shield, dan struktur aset menemukan hasil bahwa ukuran perusahaan dan total aset mempunyai hubungan positif dengan debt to equity ratio. Sementara profitabilitas, pertumbuhan dan non-debt tax shield memiliki hubungan negatif dengan debt to equity ratio.

Morri dan Cristanziani (2009) tentang determinan struktur modal pada perusahaan real estate di Eropa. Hasil temuannya bahwa profitabilitas, pertumbuhan perusahaan, dan risiko bisnis memiliki hubungan negatif dengan debt to equity ratio. Sementara struktur aset, biaya modal dan struktur kepemilikan memiliki hubungan positif dengan debt to equity ratio. Yunus (2002) dalam penelitiannya Determinant of Capital structure of the Property Companies in Malaysia mendapati growth rate, cost borrowing, firm size memiliki hubungan positif dengan hutang jangka panjang, sedangkan tax ratememiliki hubungan negatif dengan hutang jangka panjang.

Hasil penelitian Sheikh dan Zongjun (2011) tentang determinan struktur modal pada perusahaan manufaktur di Pakistan dengan menggunakan data sample 160 perusahaan yang listing di Karachi stock exchange (2003-2007) adalah bahwa profitabilitas, likuiditas, volatilitas laba, dan struktur aset memiliki hubungan negatif dengan debt to equity ratio. Sedangkan ukuran perusahaan berhubungan positif terhadap debt to equity ratio. Non-debt tax shicld dan pertumbuhan tidak berpengaruh secara signifikan terhadap debt to equity ratio. 
Penelitian di Indonesia yang dilakukan Seftianne dan Handayani (2011) tentang faktorfaktor yang mempengaruhi struktur modal. Dalam temuannya mengahasilkan variabel ukuran perusahaan dan pertumbuhan berpengaruh terhadap struktur modal, sedangkan variabel kepemilikan managerial, risiko bisnis, profitabilitas, likuiditas, dan struktur aset tidak berpengaruh terhadap struktur modal. Selanjutnya Nugroho (2006) menemukan hasil penelitian bahwa likuiditas, struktur aktiva, pertumbuhan, price earning ratio, memiliki hubungan positif dengan debt to equity ratio, sementara operating leverage dan profitabilitas memiliki hubungan negatif dengan debt to equity ratio. Mayangsari (2001) tentang analisis faktorfaktor yang mempengaruhi keputusan pendanaan perusahaan, hasil penelitiannya menyatakan bahwa ukuran perusahaan, laba bersih, struktur aktiva, dan perubahan modal kerja secara signifikan mempengaruhi keputusan pendanaan eksternal. Kusumawijaya (2011) melakukan penelitian tentang pengaruh struktur modal dan pertumbuhan perusahaan terhadap profitabilitas dan nilai perusahaan, hasil penelitiannya menyatakan bahwa struktur modal dan pertumbuhan berpengaruh signifikan positif terhadap nilai perusahaan.

Dalam menentukan keputusan pendanaan perlu diperhatikan komposisi struktur modal agar dapat diperoleh struktur modal yang optimal. Struktur modal adalah perbandingan antara utang jangka panjang dengan modal sendiri (Moeljadi, 2006) Struktur modal merupakan bagian dari struktur keuangan yaitu bagaimana perusahaan membiayai struktur aktivanya (Sugiharto, 2009)

Trade off theory atau balancing theorymemprediksi bahwa dalam mencari hubungan antara struktur modal dengan nilai perusahaan terdapat suatu tingkat leverage (debt ratio) yang optimal. Berbeda dengan teori Pecking orderyang pertama kali dikenalkan tahun 1961 oleh Profesor Gordon Donaldson yang melakukan survei bagaimana sebenarnya perusahaan membangun struktur modalnya. Donaldson menemukan pada saat perusahaan membutuhkan pendanaan akan cenderung menggunakan dana sendiri, bila pilihan tersebut tidak dapat digunakan maka perusahaan akan menerbitkan utang. Brealey et.al (2007) menyatakan bahwa keputusan pendanaan merupakan tanggungjawab manajer keuangan dalam menggalang dana yang dibutuhkan untuk investasi dan operasinya. Jumlah investasi menentukan jumlah pendanaan yang harus diperoleh, dan para investor yang berkontribusi mendanai saat ini mengharapkan pengembalian investasi di masa depan.

\section{METODE PENELITIAN}

Penelitian ini menggunakan pendekatan penelitian kuantitatif dengan pengujian hipotesis ( $h y-$ pothesis testing). Populasi yang digunakan dalam penelitian adalah emiten sektor properti yang ditetapkan oleh BEI sebanyak 194 (2006-2010) dengan teknik pengambilan sampel porposive sampling. Adapun teknik analisis yang digunakan dalam penelitian ini adalah regresi linier sederhana dengan uji asumsi klasik terlebih dahulu.

Beberapa variabel (profitabilitas, struktur aset, likuiditas, peluang pertumbuhan) yang digunakan dalam penelitian ini merujuk pada teori yang dikonversi dari Weston dan Copeland (1997) serta penelitian Sheikh dan Zongjun (2011), sementara variabel risiko bisnis merujuk pada penelitian Morri (2009) dan biaya modal (Brigham dan Houston, 2006) serta nilai perusahaan (Brigham dan Houston, 2006) adalah sebagai berikut.

\section{HASIL PENELITIANDAN PEMBAHASAN}

Analisis regresi linier dalam penelitian ini digunakan untuk memodelkan fungsi hubungan antara variabel dependen dan variabel independen. Variabel dependen dilambangkan dengan Z (Nilai Perusahaan), sedangkan variabel independen dilambangkan dengan Y (Struktur Modal), model regresi yang didapat sebagai berikut: $Z=0,027+$ $0,192 Y+e$. Sebelum model digunakan dalam uji hipotesis terlebih dahulu dilakukan uji asumsi klasik. Setelah uji asumsi klasik terpenuhi maka model regresi dapat digunakan dalam pengujian hipotesis, hipotesis dilakukan secara bertahap dengan tahap pertama menguji pengaruh determinan struktur modal dan tahap kedua menguji pengaruh struktur modal terhadap nilai perusahaan. 
Tabel 1. Variabel Penelitian

\begin{tabular}{cll}
\hline No & \multicolumn{1}{c}{ Variabel } & \multicolumn{1}{c}{ Rumus } \\
\hline 1 & Struktur Modal & Debt to Equity ratio $=\frac{\text { Total debt }}{\text { Total equity }}$ \\
2 & Nilai Perusahaan & Price book value $=\frac{\text { Ekuitas Saham biasa }}{\text { Jumla } \text { h saham beredar }}$ \\
3 & Profitabilitas & EBT to total assets $=\frac{\text { EBT }}{\text { Total Aset }}$ \\
4 & Ukuran perusahaan & total of sales \\
5 & Struktur Aset & Struktur Aset $=\frac{\text { Fixed } \text { Asset }}{\text { Total asset }}$ \\
6 & Likuiditas & Likuiditas $=\frac{\text { Aktiva lancar }}{\text { Utang lancar }}$ \\
7 & Peluang Pertumbuhan & Peluang Pertumbuhan $=\frac{\text { Pertumbu han penjualan }}{\text { Total asset }}$ \\
8 & Risiko bisnis & Risiko Bisnis $=$ standar deviasi ROA \\
9 & Biaya Modal & Biaya Modal $=\mathrm{K}_{\mathrm{Rf}}+\left(\mathrm{K}_{\mathrm{M}}-\mathrm{K}_{\mathrm{Rf}}\right) \mathrm{b}_{\mathrm{i}}$ \\
\hline
\end{tabular}

Sumber: Data diolah

Dari pengujian hipotesis dengan model regresi secara simultan didapatkan nilai $\mathrm{F}_{\text {hitung }}$ lebih besar dari $\mathrm{F}_{\text {tabel }}$ dengan degrees of freedom (df) $\mathrm{n}_{1}=7$ dan $\mathrm{n}_{2}=49(14,69>2,01)$, nilai signifikansi 0,000 kurang dari $\alpha=0,05$. Dapat disimpulkan bahwa terdapat pengaruh secara simultan antara variabel profitabilitas, ukuran perusahaan, struktur asset, likuiditas, peluang pertumbuhan, risiko bisnis, biaya modal terhadap struktur modal. Selain itu uji hipotesis juga menghasilkan R square 0,119 , hal ini dapat diartikan bahwa variabel profitabilitas, ukuran perusahaan, struktur aset, likuiditas, peluang pertumbuhan, risiko bisnis, dan biaya modal memberikan pengaruh sebesar $(11,9 \%)$ terhadap keputusan struktur modal perusahaan properti yang terdaftar dalam Bursa Efek Indonesia dan dipengaruhi faktor-faktor lain $(88,1 \%)$ yang tidak dapat diungkapkan dalam penelitian ini. Sementara dari uji secara parsial didapat hasil:

\section{Profitabilitas}

Berdasarkan model regresi diatas dapat diketahui nilai koefisien variabel profitabilitas sebesar 0,333 , Sementara dari perhitungan secara partial diperoleh nilai t- ${ }_{\text {hitung }}$ lebih besar dari t- ${ }_{\text {tabel }}(2,854$ $>1,679$ ) dengan signifikansi 0,006. Karena nilai signifikansi lebih kecil dari $\alpha=0,05$ maka hipotesis terbukti ada pengaruh signifikan positif variabel profitabilitas terhadap variabel struktur Modal (debt to equity ratio) Hal ini sejalan dengan trade off theory. Hasil dari hipotesis ini tidak mendukung penelitian Sheikh dan Zongjun (2011) yang menyatakan bahwa profitabilitas berpengaruh negatif terhadap debt to equity ratio sebagai proxi dari struktur modal.

\section{Ukuran Perusahaan}

Dari model regresi linier diatas diketahui nilai koefisien variabel ukuran perusahaan sebesar 1, 857. Sementara berdasarkan hasil pengolahan data diperoleh nilai $t_{\text {hitung }}$ kurang dari $t_{\text {tabel }}(1,443<$ 1,679) dengan nilai signifikansi 0,155 lebih besar dari $\alpha=0,05$ maka hipotesis tidak ada pengaruh variabel ukuran perusahaan terhadap struktur modal terpenuhi. Apabila tingkat signifikansi menggunakan $\alpha=0,1$ hasil uji hipotesis juga tetap menunjukkan tidak ada pengaruh ukuran perusahaan terhadap struktur modal. Hasil dari pengujian hipotesis ini mendukung penelitian Lestari (2011) yang menyatakan bahwa variabel ukuran perusahaan tidak berpengaruh terhadap struktur modal.

\section{Struktur Aset}

Model regresi linier diatas menghasilkan nilai koefisien variabel struktur asset sebesar 0,091 dengan signifikansi 0,295 lebih besar dari á $=0,05$ maupun $\alpha=0,1$, sedangkan dari pengolahan data dengan SPSS menghasilkan nilai $t_{\text {hitung }}$ kurang dari 
$\mathrm{t}_{\text {tabel }}(1,058<1,679)$ Hal ini dapat diartikan bahwa variabel struktur aset tidak berpengaruh terhadap struktur modal pada tingkat signifikansi $\alpha=0,05$ maupun $\alpha=0,1$ karena perusahaan properti ratarata memiliki total aktiva tetap lebih kecil dibandingkan aktiva lancar. Sementara aset tetap yang dimiliki diakui sebagai nilai dari persediaan, dimana persediaan tersebut dapat dijadikan sebagai agunan utang. Hasil hipotesis ini tidak mendukung penelitian dari Sheikh dan Zongjun (2011) yang menyatakan bahwa variabel struktur aset berpengaruh positif terhadap struktur modal.

\section{Likuiditas}

Berdasarkan model regresi linier diatas diperoleh nilai koefisien variabel likuiditas sebesar -0, 447dengan nilai signifikansi 0,001 lebih kecil dari $\alpha=0,05$. Pengujian hipotesis menghasilkan nilai $\mathrm{t}_{\text {hitung }}$ lebih besar dari $\mathrm{t}_{\text {tabel }}(-3,584>1,679)$ Hal ini mengindikasikan bahwa variabel likuiditas berpengaruh signifikan negatif terhadap struktur modal, dimana perusahaan properti yang memiliki likuiditas diatas rata-rata lebih banyak menggunakan sumber pendanaan internal. Hipotesis ini sejalan dengan Pecking order theoryyang lebih mengutamakan sumber pendanaan internal dari pada utang.

\section{Peluang Pertumbuhan}

Berdasarkan model regresi diatas diketahui nilai koefisien variabel peluang pertumbuhan sebesar - 0,158 dengan nilai signifikansi 0,027 lebih kecil dari $\alpha=0,05$. Sedangkan dari hasil pengolahan data diperoleh nilai $t_{\text {hitung }}$ lebih besar dari tabel $_{\text {te }}(-2,274>1,679)$ menunjukkan hubungan negatif yang signifikan. Hipotesis tersebut sejalan dengan Pecking order Theory, dimana semakin tinggi peluang pertumbuhan perusahaan properti maka semakin rendah penggunaan sumber dana ekternal. Hasil hipotesis ini mendukung penelitian dari Sayilgan, Karabacak, dan Kucukkocaouglu (2006), Morri dan Cristanziani (2009) yang menyatakan bahwa peluang pertumbuhan berpengaruh negatif terhadap debt to equity ratio.

\section{Risiko Bisnis}

Model regresi linier diatas mengahasilkan nilai koefisien variabel risiko bisnis sebesar $-0,361$ dengan nilai signifikansi 0,063 lebih besar dari $\alpha=$ 0,05 . Sedangkan dari hasil SPSS diperoleh nilai $\mathrm{t}_{\text {hitung }}$ lebih besar dari pada $\mathrm{t}_{\text {tabel }}(-1,903>1,679)$ menunjukkan ada pengaruh negatif variabel risiko bisnis terhadap struktur modal tetapi tidak signifikan. Namun jika menggunakan tingkat signifikansi $\alpha=0,1$ risiko bisnis berpengaruh signifikan terhadap struktur modal. Hipotesis ini tidak mendukung penelitian dari Sayilgan, et.al (2006), Morri dan Cristanziani (2009) yang menyatakan bahwa risiko bisnis berpengaruh secara negatif terhadap debt to equity ratio. Akan tetapi hipotesis ini konsisten dengan penelitian yang dilakukan oleh Seftianne dan Handayani (2011) menyatakan bahwa risiko bisnis tidak berpengaruh terhadap debt to equity ratio.

\section{Biaya Modal}

Berdasarkan model regresi diatas diperoleh nilai koefisien variabel biaya modal sebesar 0,346 dengan nilai signifikansi 0,02 lebih kecil dari $\alpha=$ 0,05 . Sedangkan hasil hipotesis menunjukkan niali $\mathrm{t}_{\text {hitung }}$ lebih besar dari $\mathrm{t}_{\text {tabel }}(3,299>1,679)$ Hal ini mengindikasikan bahwa variabel biaya modal sendiri berpengaruh signifikan positif terhadap struktur modal. dalam memenuhi kebutuhan pendanaan perusahaan properti, besarnya biaya modal sendiri menjadi suatu alasan bagi perusahaan untuk menggunakan sumber dana eksternal berupa utang. Hipotesis ini sejalan dengan Trade off theoryyang menyatakan bahwa untuk mendapatkan sumber pendanaan harus memperhatikan kesimbangan antara biaya dan keuntungan yang diperoleh, dimana apabila biaya modal sendiri lebih mahal maka sebaiknya menggunakan pendanaan dari utang.

\section{Struktur Modal}

Dari model regresi linier sederhana tersebut dapat diintepretasikan bahwa variabel struktur modal memiliki nilai koefisien regresi sebesar 0,192 
dengan nilai signifikansi 0,081 lebih dari $\alpha=0,05$. Sedangkan pengujian hipotesis menghasilkan nilai $\mathrm{t}_{\text {hitung }}$ lebih besar dari $\mathrm{t}_{\text {tabel }}(1,778>1,679)$ menunjukkan struktur modal berpengaruh secara positif tetapi tidak signifikan terhadap nilai perusahaan namun apabila tingkat signifikansi yang digunakan $\alpha=0,1$ menunjukan pengaruh yang signifikan. Hal ini dapat diartikan bahwa semakin tinggi nilai leverageatau struktur modal sampai pada titik tertentu (optimal) dengan komposisi utang yang lebih besar dibandingkan ekuitas maka akan memberikan manfaat (benefit) tetapi manfaat yang didapat akan menurun sejalan dengan meningkatnya biaya utang sehingga memberikan tingkat risiko yang tinggi bagi pemegang saham serta ekspektasi tingkat pengembalian juga tinggi. Kondisi dimana perusahaan dengan tingkat biaya kebangkrutan ( $f$ nancial distress) yang tingi akan berdampak terhadap turunnya nilai perusahaan.

Berdasarkan hasil uji hipotesis penelitian ini tidak mendukung sepenuhnya penelitian Kusumawijaya (2011) yang menyatakan bahwa struktur modal berpangaruh positif terhadap nilai perusahaan, sementara dalam penelitian ini struktur modal berpengaruh meskipun tidak signifikan (pada $\alpha=0,05)$ terhadap nilai perusahaan. Hal ini dikarenakan nilai perusahaan banyak dipengaruhi oleh sentimen pasar atau faktor lain yang tidak diungkap dalam penelitian ini, akan tetapi struktur modal dapat berpengaruh signifikan (pada $\alpha=0,1$ ) terhadap nilai perusahaan.

\section{SIMPULAN}

Dari hasil penelitian ini dapat disimpulkan bahwa dari tujuh variabel yang diuji (profitabilitas, ukuran perusahaan, struktur aset, likuiditas, peluang pertumbuhan, risiko bisnis, biaya modal) terdapat empat variabel yang berpengaruh signifikan terhadap struktur modal, yaitu: profitabilitas, likuiditas, peluang pertumbuhan, biaya modal.

Uji hipotesis juga dilakukan untuk mengetahui pengaruh struktur modal terhadap nilai perusahaan, dimana hasil uji tersebut menunjukkan bahwa struktur modal berpengaruh meskipun tidak signifikan terhadap nilai perusahaan, hal ini dapat diartikan bahwa nilai perusahaan lebih banyak dipengaruhi oleh indikator lain misalnya sentimen pasar atau faktor lain yang tidak diungkapkan dalam penelitian ini.

\section{DAFTAR PUSTAKA}

Bauer, P., 2004, Determinant of Capital Structure, Empirical Evidence from the Czech republic, Czech Journal of Economics and Finance, Vol 54, pp 2-21.

Booth, LArivazian, V, Demirguc-Kunt, A., and Maksimonic, V., 2001, Capital Structures in developing Countries, The Journal of Finance, Vol LVI, No 1, pp87-130.

Deesomsak, Paudyal K and pescetto G. 2004. The Determinants of capital Structure: Evidence from the Asia Pasific Region, Journal of multinational financial Management 14 (2004) pp. 387-405.

Djakman, C. D. dan G. Halomoan, 2001. Pengujian Pecking Order Hypothesis di Bursa Efek Jakarta 1994 dan 1995, Jurnal Riset Akuntansi, 4 (3): 303-313.

Eriotis, N. Vasiliou, D. and Ventoura Neokosmidi, Z, 2007, How Firm Characteristic Affect Capital structure: an Empirical Study, Managerial finance, Vol 33 No 5, pp 321331.

Fama, E.F., and French K. R. 2002. Testing trade- Off and pecking order prediction about dividend and debt, The Review of Financial Studies 15 (1) pp. 1-33.

Groth, J.C dan R.C Anderson 1997. Capital Structure: Perspective For Managers Management decision 35/7: 552-561.

http://property.kompas.com, 2011/06

Mazur, K., 2007, The Determinant of Capital Structure Choice: Evidence from Polish Companies, International advance in Economics Research, Vol 13, pp 495-514.

Michael C K, Sumner G dan Packer J. 2006. REIT Capital Structure: is it the market imposed. Managerial Finance 32 (12) pp. 981-987. 
Modligiani, F, and M. H. Miller. 1958. The Cost of Capital, corporate finance and the Theory of Investment, American Economic Review 53 pp. 261-297.

Modligiani, F, and M. H. Miller. 1963. Corporate Income taxes and the cost of capital: A correction, American Economic Review 53 pp. 433-443.

Moeljadi. 2006. Manajemen Keuangan: Pendekatan Kuantitatif dan Kualitatif jilid 1, Bayumedia. Malang.

Morri G dan Cristanziani F. 2009. What the determinant the capital structure of Real estate Companies? An analysis of the EPRA/ NAREIT Europe Index, Journal of property investment and Finance 27 (4) pp. 318-372.

Myers, Brealy, Steward C, Marcus, 2008, Dasardasar Manajemen keuangan perusahaan jilid 1 Edisi kelima, Erlangga, Jakarta.

Myers, S. C, dan N. SMaljuf 1984, Corporate financing and Investment Decision When firm Have International, Investor Do Not Have, Journal of Financial Economic, 13, 187-221.

Nugroho, Asih Suko, 2006, Analisis faktor-faktor yang mempengaruhi struktur modal perusahaan property yang go public di Bursa efek Jakarta periode tahun 1994-2004. Tesis Universitas Diponegoro Semarang.

Ooi, J, 1999, The Determinant of Capital Structure: Evidence on UK property Companies, journal of Property Investment and Finance, 17 (15): 464-480.

Ozkan, A, 2001. Determinant of Capital Structure and Adjusment to Long Run Tanget: Evidence from UK Company Panel Data, journal of Business Finance and Accounting, 28 pp 175-198.

Saidi, 2004, Faktor-Faktor yang Mempengaruhi struktur Modal pada Perusahaan Manufaktur Go Public di Bursa Efek Jakarta tahun 19972002, Jurnal Bisnis dan Ekonomi, 11 (1): 44-58.
Sayilgan, Karabacak dan Kucukkocaoglu. 2006. The firm specific determinants of corporate capital structure: evidence from Turkish panel data, Investment Management and financial innovation, vol 3 pp. 125-139.

Seftianne, Handayani Ratih, 2011, Faktor-faktor yang Mempengaruhi Struktur Modal Pada Perusahaan Publik Sektor Manufaktur, Jurnal Bisnis dan Akuntansi, Vol 13, pp 39-56.

Serrasqueiro, Z. M. S., and Rogao, M. C. R., 2009, Capital structure of Listed Portuguese Companies, Determinant of Debt Adjusment, Review of Accounting and finance, Vol 8, No 1, pp54-75.

Sheikh, N. A, dan wang Zongjun, 2011, An empirical study of Firm in Manufacturing Industry of Pakistan. Managerial Fianance vol. 37 pp. 117-133.

Soegiharto, 2009, Struktur Modal, Struktur Kepemilikan Perusahaan, Permasalahan Keagenan dan Masalah Informasi Asimetri, Graha Ilmu, Yogyakarta.

Tin, S, 2003, Analisis Faktor-faktor yang Mempengaruhi Struktur Modal Multiple regression Model, Jurnal IImiah Akuntansi, 3 (2): 30-43.

Viviani, J., 2008, Capital Structure Determinant: an Empirical Study of French Companies in the Wine Industry, International Journal of Wine Business Research, Vol. 20, No 2, pp171-194.

Weston, Fred J., copeland \& Thomas E, 1997, Manajemen Keuangan, Edisi kesembilan Jilid dua, Binarupa Aksara, jakarta.

Wibowo, A. J. dan F. J. Erkaningrum, 2002, Studi Keterkaitan antara Divident Payout ratio, financial Leverage, dan Investasi dalam Pengujian Hipotesis Pecking Order, Jurnal Ekonomi dan Bisnis Indonesia, 17 (4): 506519.

Yartey C. A. 2011. Small business Finance in sub Saharan Africa: the Case of Ghana, Management Research Review 34 (2) pp. 172-185. 
Yunus, Rahimah Binti Mohamed, 2002, Determinant of Capital structure of the Property Companies in Malaysia, A Dissertation University of Technology, Syah Alam, For the Master of Accountancy
Zou, H. and Xiao, J.Z., 2006, The financing behavior of listed Chinese firms, The British Accounting Review, Vol 38, pp 239-258. 